\title{
UTILITY OF FNAC WITH CYTOMORPHOLOGICAL PITFALLS IN INTRAORAL LESIONS- A 6-YEAR EXPERIENCE AT A TERTIARY CARE HOSPITAL
}

\author{
Prajwala Gupta1, Manjari Kishore2, Manju Kaushal', Minakshi Bhardwaj", Nishi Sharma ${ }^{5}$
}

1Associate Professor, Department of Pathology, PGIMER, Dr. Ram Manohar Lohia Hospital, New Delhi, India.

${ }^{2}$ Senior Resident, Department of Pathology, PGIMER, Dr. Ram Manohar Lohia Hospital, New Delhi, India.

3 Professor, Department of Pathology, PGIMER, Dr. Ram Manohar Lohia Hospital, New Delhi, India.

4 Professor and HOD, Department of Pathology, PGIMER, Dr. Ram Manohar Lohia Hospital, New Delhi, India.

5Professor, Department of ENT, PGIMER, Dr. Ram Manohar Lohia Hospital, New Delhi, India.

\begin{abstract}
BACKGROUND
Intraoral region has a spectrum of distinct anatomical sites and there exists a wide variety of intraoral lesions. Fine Needle Aspiration Cytology (FNAC) is a simple tool and has gained importance, especially in cases with difficult intraoral accessibility and risk of bleeding obviating biopsy and thereby helping in the decision for surgical intervention.

Aim: This study was carried out to evaluate the diagnostic utility and pitfalls of FNAC in the intraoral lesions with histopathological correlation.
\end{abstract}

ABSTRACT

\section{MATERIALS AND METHODS}

This is a retrospective descriptive study and the data was collected retrospectively of intraoral lesions diagnosed on FNAC over a period of 6 years (July 2011 to June 2017) from the cytology records. The histopathology correlation was done wherever available.

\section{RESULTS}

Out of 102 cases, 82 (80.39\%) were adequate for cytological study. Different sites involved were tongue, gingival region, buccal mucosa, floor of mouth, soft palate, hard palate, tonsil, oropharynx and parapharyngeal/ posterior pharyngeal wall. Of these 82 cases, $40(48.78 \%)$ were neoplastic and $42(51.22 \%)$ were non-neoplastic. Twenty-nine cases (72.5\%) out of 40 neoplastic cases were diagnosed as benign and 11 cases $(27.5 \%)$ as malignant. Cytological diagnosis was compared with the histopathology diagnosis. Histological correlation was found in 44 cases with concordance rate of $68.2 \%$ (30 of 44 cases). However, in 9 case s there was discordance with histological findings. In rest 5 cases, the histology report was descriptive without a definitive diagnosis. A single false positive case was of dense inflammation with squamous cells misinterpreted as squamous cell carcinoma on cytology.

\section{CONCLUSION}

FNAC was found to be useful in the diagnosis of variety of lesions in the oral cavity, though few cases can pose diagnostic difficulties. Cytological diagnosis can save many non-neoplastic cases from undergoing surgery or excision biopsy and helps identify the malignant cases for early management.

\section{KEY WORDS}

FNAC, Oral Lesions, Palate, Tongue, Histology.

HOW TO CITE THIS ARTICLE: Gupta P, Kishore M, Kaushal M, et al. Utility of FNAC with cytomorphological pitfalls in intraoral lesions- a 6-year experience at a tertiary care hospital. J. Evolution Med. Dent. Sci. 2018;7(40):4361-4365, D0I: $10.14260 /$ jemds/2018/973

\section{BACKGROUND}

Fine Needle Aspiration Cytology (FNAC) is a well-established, simple and prompt diagnostic modality for lesions of head and neck, especially swellings in thyroid gland, salivary gland and lymph nodes.[1-11] However, its use in intraoral lesions is limited.[2-10] This may be because of the unapproachable lesion and non-compliance from the patient. FNAC can

'Financial or Other Competing Interest': None.

Submission 27-07-2018, Peer Review 13-09-2018,

Acceptance 21-09-2018, Published 01-10-2018.

Corresponding Author:

Dr. Manjari Kishore,

Senior Resident,

Department of Pathology,

Room No. 310, 3rd Floor, OPD Building,

Dr. RML Hospital, Baba Kharak Singh Maarg,

New Delhi, India.

E-mail:drmanjarik@gmail.com

DOI: $10.14260 /$ jemds $/ 2018 / 973$

\section{(c) $(1)$}

provide an early probable diagnosis and help the clinicians in avoiding or choosing the surgical interventions wherever applicable.[4-12] Here, we present a series of cases of intraoral lesions diagnosed on cytology in the past 6 years along with their histological correlation and the cytomorphological pitfalls.

\section{MATERIALS AND METHODS}

This is a retrospective descriptive study conducted at a tertiary care hospital over a period of 6 years (July 2011 to June 2017). The retrospective data of FNAC of a total 102 cases were obtained. In all cases, FNA was performed intraorally with a 22-gauge needle attached to $5 \mathrm{~mL}$ disposable syringe. In cases of swelling in parapharyngeal region or posterior pharyngeal wall help from the ENT specialists were taken to perform the FNA. Subsequently, both air dried and wet fixed smears were prepared using Giemsa and Papanicolaou stains, respectively. Special stain like ZiehlNeelsen stain was also done wherever required. Inadequate 
smears were those with only haemorrhagic material or only sparse benign squamous epithelial cells with blood.

A cytological diagnosis included non-neoplastic or neoplastic lesions (Benign/ Malignant) with further mentioning about the definitive cytological diagnosis. Otherwise, a descriptive report with inconclusive or suspicious findings were recorded. Histopathological correlation was done wherever available and considered as gold standard. Statistical analysis was done, and validity rate of cytological results were compared with histological diagnosis.

\section{RESULTS}

Out of 102 cases of intraoral FNAC, 82 cases were adequate for cytological evaluation. The rest 20 cases were inadequate for diagnosis and showed either only blood or sparse benign squamous epithelial cells. Among the total adequate cases $(\mathrm{n}=82), 48$ (58.54\%) were male and 34 (41.46\%) were female. Male: female (M:F) ratio was 1.4: 1 . The age of the patients ranged from 8 years to 95 years with a mean age of 45.2 years. The overall distribution of cases according to age revealed maximum number of cases in the age group of 31-50 years when combined together [Table 1].

FNAC was performed from different intraoral sites like tongue [Figure $1 \mathrm{~B}$ and $\mathrm{C}$ ], gingival region, buccal mucosa, floor of mouth, soft palate [Figure 1A], hard palate [Figure 1D], tonsil, oropharynx, parapharyngeal/ posterior pharyngeal wall. It was noted that most of the intraoral lesions were located in hard palate and tongue and maximum neoplastic lesions were encountered in hard palate [Table 2].

On cytological evaluation of the total 82 cases, 42 $(51.22 \%)$ were non-neoplastic and 40 (48.78\%) were neoplastic. The non-neoplastic category comprised of- 1) Cystic lesions like epidermal inclusion cyst (EIC), thyroglossal cyst and mucocele/ mucus retention cyst; 2) Inflammatory like non-specific acute and chronic inflammation/ abscess or granulomatous lesion; 3) Vascular lesions; 4) Parasitic infestation like cysticercosis. Non-specific inflammatory pathology was the most common non-neoplastic lesion (22 of $42 ; 52.38 \%$ of all non-neoplastic lesions) were noted in the study [Table 3]. An uncommon case of granulomatous lesion of tongue was also found [Figure $1 \mathrm{~B}$ and $2 \mathrm{C}$ ]. However, ancillary investigations ruled out tuberculosis and the patient responded to medical treatment.

The neoplastic category comprised of 29 (72.5\%) benign lesions and 11 malignant cases $(27.5 \%)$ and site wise distribution was recorded [Table 4]. Of all the benign neoplastic lesions, the most common was pleomorphic adenoma (18 of 29; 62.07\%) followed by haemangioma (5 of $29 ; 17.2 \%), 2$ cases each of Warthin's tumour and lipoma (6.9\% each) and 1 case each of Schwannoma and inflammatory pseudotumour (3.4\% each). The diagnosis of haemangioma was given on cytology in correlation with the radiological diagnosis of haemangioma; hence, aspiration of blood in such cases were not labelled as inadequate.

Among the total 11 malignant cases, squamous cell carcinoma was the most common malignancy (5 of 11; $45.45 \%$ cases of all malignant lesions) followed by adenoid cystic carcinoma (4 of $11 ; 36.36 \%$ ) and 1 case each of low grade mucoepidermoid carcinoma and non-Hodgkin's lymphoma ( $9 \%$ each).
Histopathology was available in 44 of 102 cases (43.14\%). In majority of the neoplastic cases, the histopathological findings were concordant with those of cytological diagnosis [Table 4]. Among non-neoplastic lesions, histology was available in 7 cases. A good correlation was noted in non-neoplastic lesions with histological concordance noted in six of the seven cases (85.71\%). One case diagnosed on cytology as epidermal inclusion cyst was reported as squamous papilloma on histology [Figure 2D].

In neoplastic lesions, histological diagnosis was available in 42 cases [Table 4]. A positive concordance rate was noted in 34 of 42 cases (88.89\%). The highest concordance was noted in the diagnosis of pleomorphic adenoma with 13 of the 14 cases (92.86\%); however, one case showed low-grade mucoepidermoid carcinoma on histology which was reported as pleomorphic adenoma on cytology [Figure 2A]. 2 cases of haemangioma diagnosed on cytology had histological findings and only 1 case showed positive correlation. One case of Schwannoma diagnosed on cytology correlated on histology. In Schwannoma, loose clusters of spindle cells are noted with long slender nuclei.

Statistical analysis was done in both benign as well as malignant cases. After correlating the cytological results with histology findings in benign cases, the following results were obtained: - Sensitivity- 100\%, Specificity- 83.33\%, Positive predictive value- $88.24 \%$, Negative predictive value- $100 \%$ and Positive likelihood ratio- 6 . Validity rate of $92.59 \%$ was obtained in patients with benign lesions.

Among malignant lesions, all cases of adenoid cystic carcinoma (3 cases) and mucoepidermoid carcinoma (2 cases) had respective histological correlation. There were five cases of squamous cell carcinoma diagnosed on cytology. However, one case was reported falsely positive. The case was reviewed again, which showed dense inflammation and necrosis with few atypical squamous cells; morphology of which was not discernible along with bare nuclei in the background. The reactive atypia probably led to the misdiagnosis [Figure 2B].

There were five false negative cases, which were mainly attributed to sampling error and inadequacy of sample on cytology. These five cases were diagnosed as pleomorphic adenoma ( 3 cases), haemangioma ( 1 case) and squamous cell carcinoma (1 case) on histology. There were five cases which were either inadequate or given a descriptive diagnosis on cytology and these five cases were found to be inadequate on histology as well.

On applying the similar set of statistical analysis in malignant cases, the following results were obtained: Sensitivity- $64.29 \%$ with Positive predictive value- $90 \%$. An overall validity rate of $67 \%$ was obtained in malignant cases.

\begin{tabular}{|c|c|}
\hline Age Group (In Years) & Number of Cases (\%) \\
\hline $0-10$ & $02(2.43)$ \\
\hline $11-20$ & $04(4.90)$ \\
\hline $21-30$ & $06(7.31)$ \\
\hline $31-40$ & $23(28.05)$ \\
\hline $41-50$ & $29(35.37)$ \\
\hline $51-60$ & $08(9.75)$ \\
\hline$>60$ & $10(12.2)$ \\
\hline
\end{tabular}

Table 1. Age-Wise distribution of Intraoral Lesions $(n=82)$ 


\begin{tabular}{|c|c|c|c|}
\hline $\begin{array}{c}\text { Sl. } \\
\text { No. }\end{array}$ & Site & $\begin{array}{c}\text { Total } \\
\text { No. of Cases } \\
\mathbf{( \% ) ,} \\
\mathbf{n = 8 2}\end{array}$ & $\begin{array}{c}\text { Number of } \\
\text { Neoplastic } \\
\text { Lesions on } \\
\text { Cytology } \\
\text { (n=40) }\end{array}$ \\
\hline 1. & Tongue & $24(29.27)$ & 04 \\
\hline 2. & Gingival/ Gum region & $02(2.44)$ & 02 \\
\hline 3. & Buccal mucosa & $10(12.20)$ & 02 \\
\hline 4. & Floor of mouth & $06(7.31)$ & 01 \\
\hline 5. & Soft palate & $07(8.54)$ & 03 \\
\hline 6. & Hard palate & $25(30.49)$ & 22 \\
\hline 7. & Tonsil & $04(4.88)$ & 02 \\
\hline 8. & Oropharynx & $01(1.22)$ & 01 \\
\hline 9. & Parapharyngeal/ & $03(3.66)$ & 03 \\
\hline Tosterior pharyngeal wall & 03 r \\
\hline
\end{tabular}

Table 2. Site-Wise distribution of Intraoral Lesions (n= 82)

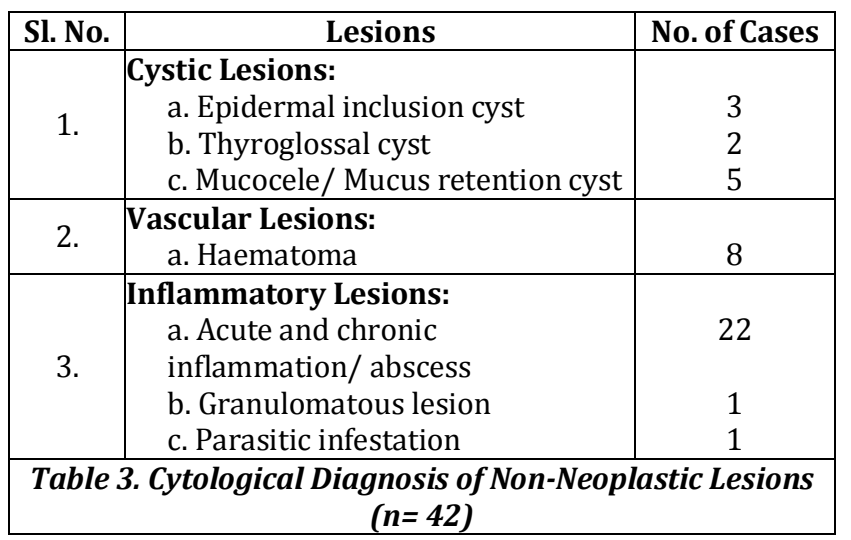

\begin{tabular}{|c|c|c|}
\hline \multicolumn{2}{|r|}{ Cytological Diagnosis } & $\begin{array}{c}\text { Histological } \\
\text { Correlation }\end{array}$ \\
\hline \multicolumn{3}{|l|}{ Benign } \\
\hline & $\begin{array}{l}\text { a. Pleomorphic adenoma }(\mathrm{n}= \\
14)\end{array}$ & 13 \\
\hline & b. Haemangioma $(n=2)$ & 01 \\
\hline & c. Schwannoma $(n=1)$ & 01 \\
\hline \multicolumn{3}{|c|}{ Malignant } \\
\hline a. & Adenoid cystic carcinoma $(\mathrm{n}=3)$ & 3 \\
\hline b. & $\begin{array}{l}\text { Low-grade mucoepidermoid } \\
\text { carcinoma }(n=2)\end{array}$ & 2 \\
\hline c. & Squamous cell carcinoma $(n=5)$ & 4 \\
\hline \multicolumn{3}{|c|}{$\begin{array}{c}\text { Table 4. Cytological Diagnosis of Neoplastic Lesions with } \\
\text { Histologic Correlation }(n=27)\end{array}$} \\
\hline
\end{tabular}

\section{DISCUSSION}

Intraoral lesions comprise a wide variety of pathologic lesions with distribution at many distinct anatomical sites.[2-12] The aetiology of intraoral lesions is not exactly known. However, allergic reaction, dietary habits, betel nut chewing, tobacco use and vitamin deficiency have been noted as underlying causes in many cases. The prevalence rate of intraoral lesions varies from $0.2-0.6 \%$ with male preponderance.[4-7]

Though biopsy is used commonly to diagnose these intraoral lesions, but it requires anaesthesia and pose problems in diagnosing the transmucosal lesions. FNAC is frequently used in diagnosis of lesions of head and neck region, but its role in evaluation of intraoral lesions is limited.[4-10] This is due to the inaccessibility of the intraoral lesions and poor patient's compliance. Other factors which decrease the sensitivity and specificity of FNAC are small size and deeper location of lesions which make it difficult to fix these lesions during FNAC.
However, FNAC can still help in the preliminary evaluation of these lesions and help the clinicians in avoiding unnecessary surgical intervention in many non-neoplastic cases as noted in the present study. There are studies in the literature presenting the role of FNAC in the diagnosis of these intraoral lesions.[2-20] The present study attempts to highlight the reliability and pitfalls of FNAC in differentiating the non-neoplastic and neoplastic conditions.

Singhal et al[5] and Gupta et al[6] included 55 and 157 cases of intraoral lesions in their studies respectively with inadequacy noted in $10 \%$ and $07 \%$ respectively. However, inadequacy was seen in $19 \%$ cases in the present study. The overall frequency of malignant intraoral lesions is varying in the literature ranging from $20 \%$ to $70 \%$, whereas it was $30 \%$ in our study[5-9] [Table 5].

The age of the patients in our study ranged from 8 years to 95 years with a mean age of 45.2 years and preponderance of cases in adult. A wide range of age in patients was noted in other studies as well.[2-15]

In the present study, most intraoral lesions encountered were in hard palate and tongue. Sakarwal et al[10] reported majority of lesions from the buccal mucosa. Few other studies also showed different regions like pharynx/ oropharynx, mandible and palate as common sites of aspiration. ${ }^{[5-20]}$

Among the non-neoplastic cases, non-specific inflammation was noted as the most common lesion and few studies including those by Singh et al[11] and Sakarwal et al[10] also noted similar findings. A solitary case of granulomatous lesion of tongue was also noted in the present study; however, specific aetiology could not be established. It is uncommon to find such lesion on the tongue.

A positive correlation was noted in 24 of 27 cases $(88.89 \%)$ of neoplastic lesion with highest concordance noted in the diagnosis of pleomorphic adenoma. Abrari et al[12] also reported similar findings.

FNA of pleomorphic adenoma yields thick mucoid to myxoid material, which sometimes become difficult to spread. Cytology reveals ductal epithelial cells, myoepithelial cells and chondromyxoid matrix material. Some cases may show predominantly matrix material with scanty cells or the reverse with abundant myoepithelial and ductal cells; thereby, posing diagnostic difficulties. In our series also, one case of pleomorphic adenoma diagnosed on cytology ultimately came out as mucoepidermoid on histology. This may be due to the interpretation of matrix material as mucus along with presence of squamous metaplastic cells.

Squamous Cell Carcinoma (SCC) was the most common malignant lesion and its frequency in our study was $45 \%$. On reviewing the literature, there was variation in frequency of intraoral SCC.[18-25] A solitary case of non-Hodgkin's lymphoma noted in the current study was tonsillar in origin. A study by Deng et al[13] found metastatic lesions in the intraoral region. However, no such case was noted in the present study.

Positive histological correlation was noted in all cases of adenoid cystic carcinoma and mucoepidermoid carcinoma and four out of the five squamous cell carcinoma cases. Adenoid cystic carcinoma reveals hyaline globules; however, no myoepithelial cells are embedded in this matrix. Tumour cells are seen in sheets and dispersed. Cells are monomorphic with scanty cytoplasm, high N: C ratio. Necrosis is usually not seen. Mostly the diagnosis is straight forward; however, 
problem arises in solid variant which lacks hyaline globules. In such cases, differentiating the basal cell adenoma and polymorphous low-grade adenocarcinoma becomes difficult. Secondly, mucoepidermoid carcinoma shows predominantly three types of cells: Squamous cells, Intermediate cells and Mucus secreting cells. Background is dirty with mucus and debris. Diagnosis of high-grade mucoepidermoid carcinoma is easier as compared to low-grade, as it may often be mistaken as retention cyst, Warthin's tumour, cystic pleomorphic adenoma or metastatic squamous cell carcinoma with cystic changes.

One case diagnosed as SCC on cytology showed only reactive squamous epithelium on histology. A false positive diagnosis was due to scant representative material along with areas of inflammation, foci of necrosis and atypia on cytology.

Gupta et al[6] also reported a false-positive case due to inflammatory atypia misinterpreted as SCC on cytology. This emphasises the fact that a diagnosis of SCC in the presence of inflammation should be offered with extreme caution.

There were five false negative cases in the present study, which were mainly attributed to sampling error and inadequacy of sample on cytology. Gupta et al[6] reported eight false-negative cases of which 6 were due to sampling error, highlighting the fact that sampling of intraoral lesions on FNAC poses problems and can lead to false negative results. The sampling difficulty in some cases was further substantiated by the fact that the five cases which were given a descriptive diagnosis on cytology were found to be inadequate on histology as well. These cases qualify for the need of repeat FNAC or biopsy. In the present series, 88.90\% cases had concordant histological correlation [Table 5].[5-9]

\begin{tabular}{|c|c|c|c|c|}
\hline $\begin{array}{c}\text { Study } \\
\text { Reviewed }\end{array}$ & $\begin{array}{c}\text { Number } \\
\text { of } \\
\text { Cases }\end{array}$ & $\begin{array}{c}\text { Inadequacy } \\
\text { (\%) }\end{array}$ & $\begin{array}{c}\text { Histological } \\
\text { Correlation } \\
\text { (\%) }\end{array}$ & $\begin{array}{c}\text { Frequency of } \\
\text { Malignant } \\
\text { Intraoral } \\
\text { Lesions (\%) }\end{array}$ \\
\hline $\begin{array}{c}\text { Gilani et } \\
\text { al,[7] 2012 }\end{array}$ & 40 & 13.1 & 96.80 & 77 \\
\hline $\begin{array}{c}\text { Mondal et } \\
\text { al,[8] 2009 }\end{array}$ & 54 & 3.7 & 97.00 & 18.2 \\
\hline $\begin{array}{c}\text { Gandhi et } \\
\text { al,[9] 2011 }\end{array}$ & 98 & 11 & 90.00 & 28.0 \\
\hline $\begin{array}{c}\text { Gupta et } \\
\text { al,[6] 2012 }\end{array}$ & 157 & 07 & 87.70 & 60.0 \\
\hline $\begin{array}{c}\text { Singhal et } \\
\text { al,[5] 2015 }\end{array}$ & 55 & 10 & 94.12 & 50.0 \\
\hline $\begin{array}{c}\text { Present } \\
\text { Study, } \\
\text { 2017 }\end{array}$ & 102 & 19 & 81.00 & 30.0 \\
\hline \multicolumn{7}{|c|}{ Table 5. Comparative Data of Intraoral FNAC with } \\
\multicolumn{5}{|c|}{ different Studies[5-9] } \\
\hline
\end{tabular}

It is a well-known fact that FNAC is considered as a simple and rapid diagnostic modality for preliminary examination of intraoral lesions. It helps in diagnosing a wide spectrum of lesions in this region. Non-neoplastic lesions can be managed conservatively and an early intervention can be made in malignant cases.[25-32] Sampling error, especially due to patient compliance and unapproachable location attributes to the false negative cases. [20-32] The present study highlights the importance of FNAC in differentiating the non-neoplastic and neoplastic intraoral lesions, thereby guiding further clinical management.

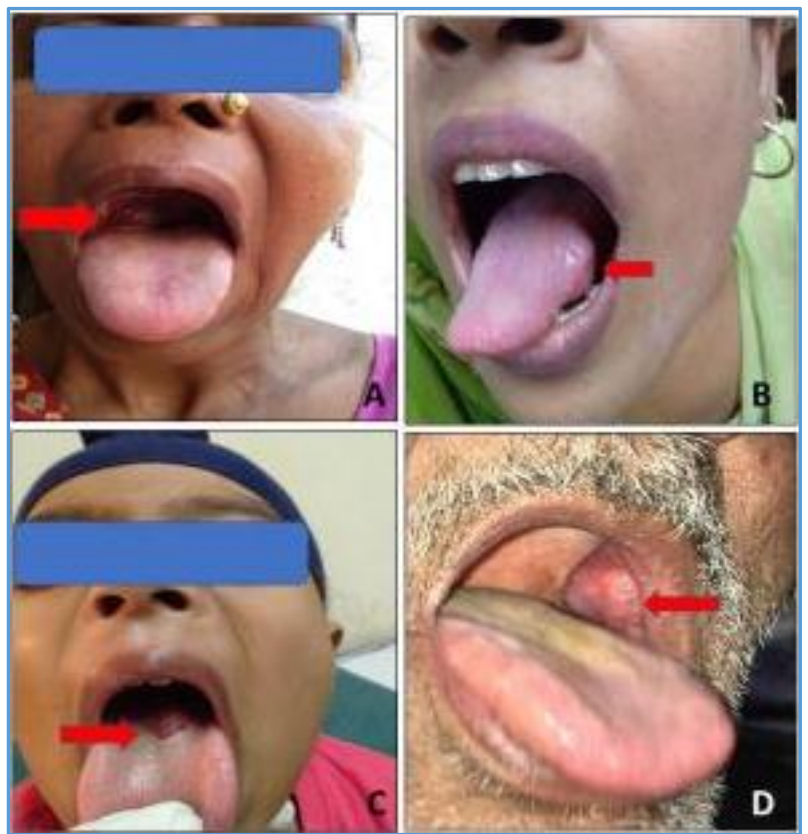

Figure 1 A-D. A-Swelling over Soft Palate; B-Diffuse Swelling on Ventral Surface of Tongue; $C$-Swelling at posterior one-third of the Tongue; D-Large Swelling noted on Hard Palate

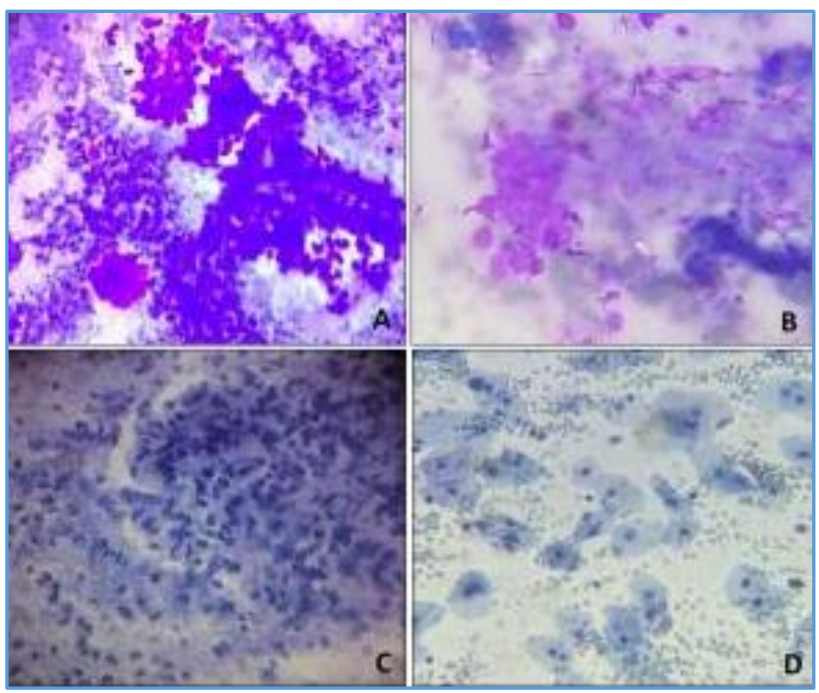

Figure 2 A-D. A-Cellular Smear showing Clusters of Epithelial Cells with areas of Myxoid Matrix [Giemsa, 200X]; B-Smear showing Epithelial Cells Cluster with Atypia and Focal Keratinous Debris [Giemsa, 400X]; CSmears from Tongue Swelling revealing Acute and Chronic Inflammatory Cells along with Epithelioid Cell Granuloma [Pap, 200X]; D-Smear showing many benign Mature Squamous Cells in a Haemorrhagic Background [Pap, 400X]

\section{CONCLUSION}

FNAC was found to be useful in the diagnosis of variety of lesions in the oral cavity, though few cases can pose diagnostic difficulties. Cytological diagnosis can save many non-neoplastic cases from undergoing surgery or excision biopsy and helps in identifying the malignant cases for early management. 


\section{REFERENCES}

[1] Schelkun PM, Grundy WG. Fine-needle aspiration biopsy of head and neck lesions. J Oral Maxillofac Surg 1991;49(3):262-7.

[2] Cramer $\mathrm{H}$, Lampe $\mathrm{H}$, Downing P. Intraoral and transoral fine needle aspiration. A review of 25 cases. Acta Cytol 1995;39(4):683-8.

[3] Bhambhani S, Das DK, Luthra UK. Fine needle aspiration cytology in the diagnosis of sinuses and ulcers of the body surface (skin and tongue). Acta Cytol 1991;35(3):320-4.

[4] Das DK, Gulati A, Bhatt NC, et al. Fine needle aspiration cytology of oral and pharyngeal lesions. A study of 45 cases. Acta Cytol 1993;37(3):333-42.

[5] Singhal N, Khurana U, Handa U, et al. Intra-oral and oropharyngeal lesions: role of fine needle aspiration cytology in the diagnosis. Indian J Otolaryngol Head Neck Surg 2015;67(4):381-7.

[6] Gupta N, Banik T, Rajwanshi A, et al. Fine needle aspiration cytology of oral and oropharyngeal lesions with an emphasis on the diagnostic utility and pitfalls. J Can Res Ther 2012;8(4):626-9.

[7] Gillani M, Akhtar F, Ali Z, et al. Diagnostic accuracy, sensitivity, specificity and positive predictive value of fine needle aspiration cytology (FNAC) in intraoral tumors. Asian Pac J Cancer Prev 2012;13(8):3611-5.

[8] Mondal P, Basu N, Gupta SS, et al. Fine needle aspiration cytology of parapharyngeal tumors. J Cytol 2009;26(3):102-4.

[9] Gandhi S, Lata J, Gandhi N. Fine needle aspiration cytology: a diagnostic aid for oral lesions. J Oral Maxillofac Surg 2011;69(6):1668-77.

[10] Sakarwal N, Awasthi S, Dutta S, et al. Fine needle aspiration cytology: a diagnostic tool for oral lesions. Int J Sci Stud 2015;3(2):90-4.

[11] Singh D, Sinha BK, Shyami G, et al. Efficacy of fine needle aspiration cytology in the diagnosis of oral and oropharyngeal tumors. Arch Int Otorhinolaryngol 2008;12:99-104.

[12] Abrari A, Ahmad SS, Bakshi V. Cytology in the otorhinolaryngologist's domain- a study of 150 cases, emphasizing diagnostic utility and pitfalls. Indian J Otolaryngol Head Neck Surg 2002;54(2):107-10.

[13] Deng FM, Hsu J, Khurana KK. Transmucosal fine needle aspiration of oral and pharyngeal lesions. ISRN Pathol 2011;2011:267145.

[14] Saleh HA, Clayman L, Masri H. Fine needle aspiration biopsy of intraoral and oropharyngeal mass lesions. Cytojournal 2008;5:4-12.

[15] Sahai K, Kapila K, Dahiya S, et al. Fine needle aspiration cytology of minor salivary gland tumours of the palate. Cytopathology 2002;13(5):309-16.

[16] Yih WY, Kratochvil FJ, Stewart JC. Intraoral minor salivary gland neoplasms: Review of 213 cases. J Oral Maxillofac Surg 2005;63(6):805-10.

[17] Kolokotronis A, Konstantinou N, Christakis I, et al. Localized B-cell non-Hodgkin's lymphoma of oral cavity and maxillofacial region: a clinical study. Oral Surg Oral Med Oral Pathol Oral Radiol Endod 2005;99(3):303-10.
[18] Vaswani B, Shah M, Shah PM, et al. Non-Hodgkin's lymphoma of tongue - a case report. Ind J Med Paediatr Oncol 2008;29:59-61.

[19] De Leon RE, Aguirre A. Oral cysticercosis. Oral Surg Oral Med Oral Pathol Oral Radiol Endod 1995;79(5):572-7.

[20] Delgado-Azañero WA, Mosqueda-Taylor A, CarlosBregni R, et al. Oral cysticercosis: a collaborative study of 16 cases. Oral Surg Oral Med Oral Pathol Oral Radiol Endod 2007;103(4):528-33.

[21] Buchner A, Merrell PW, Carpenter WM. Relative frequency of intra-oral minor salivary gland tumors: a study of 380 cases from northern California and comparison to reports from other parts of the world. J Oral Pathol Med 2007;36(4):207-14.

[22] Cerulli G, Renzi G, Perugini M, et al. Differential diagnosis between adenoid cystic carcinoma and pleomorphic adenoma of the minor salivary glands of palate. J Craniofac Surg 2004;15(6):1056-60.

[23] Gross M, Maly B, Goldfarb A, et al. Basal cell adenocarcinoma in a buccal minor salivary gland. Acta Otolaryngol 2004;124(2):213-6.

[24] Aydin E, Turkoglu S, Ozen O, et al. Mucinous cystadenocarcinoma of a minor salivary gland in the upper lip: case report. Auris Nasus Larynx 2005;32(3):301-4.

[25] Stanley MW. Selected problems in fine needle aspiration of head and neck masses. Mod Pathol 2002;15(3):342-50.

[26] Stewart CJ, MacKenzie K, McGarry GW, et al. Fineneedle aspiration cytology of salivary gland: a review of 341 cases. Diagn Cytopathol 2000;22(3):139-46.

[27] Helsel JC, Bardales RH, Mukunyadzi P. Fine-needle aspiration biopsy cytology of malignant neoplasms of the sinonasal tract. Cancer Cytopatology 2003;99(2):105-12.

[28] Baehner F, Sudilovsky D. Fine needle aspiration cytology of intraoral epithelioid hemangioma. A report of two cases. Acta Cytol 2003;47(2):275-80.

[29] Kawahara A, Harada H, Yokoyama T, et al. Cytomorphologic features of a polymorphous lowgrade adenocarcinoma of the palate. A report of 2 cases with immunocytochemistry. Acta Cytol 2003;47(6):1127-30.

[30] Oliai BR, Sheth S, Burroughs FH, et al. "Parapharyngeal space" tumors: a cytopathological study of 24 cases on fine-needle aspiration. Diagn Cytopathol 2005;32(1):11-5.

[31] Goyal S, Sharma S, Diwaker P. Diagnostic role and limitations of FNAC in oral and jaw swellings. Diagn Cytopathol 2015;43(10):810-8.

[32] Chatterjee DN, Mondal A. Peroral fine needle aspiration cytology of parapharyngeal tumors: a study of 67 cases. Indian J Otolaryngol Head Neck Surg 2009;61(Suppl 1):31-4. 